\title{
Support System for Large Diverse Groups of Open and Distance Learning Students in Indonesia
}

\author{
Aminudin Zuhairi, Siti Julaeha, T. Eduard A. Sinar \\ Universitas Terbuka
}

\begin{abstract}
This paper presents a case study on implementing support system for large and diverse groups of open and distance learning (ODL) students, based on the specific experience of Universitas Terbuka (UT) in Indonesia. The paper begins with a brief introduction of UT, its context, operational system, and programs, followed by discussion on what, why and how support system is crucial in ODL. Discussion on ODL support system includes core businesses of $O D L$ related to student registration, production and distribution of learning materials, and provision of services by the Regional Office. Student learning support services in ODL are vital to assist student learning, and this is done through various means, such as face-to-face tutorials, online tutorials, and academic counselling. Assessment of student learning is conducted using various methods and instruments, such as tutorial assignments, portfolio and performance assessment, semester examination, and program final assignment. Examination can be taken using paper and pencil test and online examination system as alternative. Use of information and communication technology (ICT) is critical to support management and learning support services in modern ODL system. Discussion on quality assurance system focuses on how ODL support system for students meet quality criteria and standards set internally by the ODL institution as well externally by the accreditation agencies and other stakeholders. ODL support system may vary from one ODL institution to another, depending on the specific context and unique needs of students and stakeholders in their respective contexts. However, there is great confidence that each of the $O D L$ institutions generally adheres to common $O D L$ principles and good practices that are universal to an ODL environment. This paper concludes that provision of effective support system is designed in such a way to facilitate student learning and ensure that services provided meet stakeholders' requirements and students' expectations.
\end{abstract}

\section{Introduction}

Open and distance learning (ODL) has been considered by many governments as one of the viable avenues for expanding access and engaging community participation in quality higher education that can be afforded by a large segment of the society. Governments throughout the world have constructed the necessary legal foundations, and regulatory as well as policy frameworks to ensure that ODL system can be effectively implemented and widely accepted by the community in response to increasing demands for lifelong learning at compulsory as well post-compulsory levels of education. Many governments have established open universities and provided proper funding for ODL courses and programs to reach diverse clients. In many countries, governments have even gone further to allow and encourage the operations of privately funded Open University and ODL systems or programs.

Governments have also acknowledged recent development in ODL that embraces e-learning and enhances uses of information and communication technology (ICT) in teaching and learning, including in ODL system. At institution levels, both open universities and other ODL systems have flourished through provision of online courses and programs. Some open universities and ODL systems have surpassed the traditional knowledge ownerships and are willing to share their knowledge resources through its freely available knowledge repositories, now commonly known as open educational resources (OER), open to the public. Even some Ivy League higher education institutions in the United States, i.e., Harvard University, Massachusetts Institutive of Technology (MIT), and University of California Berkeley, have developed collaborative effort through edX project that allows their courses freely available interactively online [2]. Any interested individuals irrespective of nationalities and previous educational backgrounds can take online courses at no charge, sit for the examinations, and acknowledge transfer of credits for such courses. These online courses have attracted thousands of participants irrespective of geographic residence. Online ODL system has made possible the sharing of knowledge and credit recognition in ways that make participation and engagement in learning in higher education easier and cheaper.

Despite the opportunity open to students in its widest sense, retention is a challenge in any open, distance and elearning course. The challenge for any ODL institution is design an open and online course in such a way that guides the ODL students to complete the course successfully and develop 
competencies that are relevant and useful to the world of work in their respective professions. Open and free online courses may attract a huge number of course enrolments and participations, but is likely that not all of them can actually complete the course successfully, and some of the students just take the online course for professional enrichment.

For Indonesia, back in 1984, in response to the growing needs for lifelong learning and leverage access and participation in higher education, the government established Universitas Terbuka (UT) with the aims of meeting increasing demands for higher education by senior high school graduates unable to get access to the face-to-face mode of higher education system. Since its inception, the UT has proven itself as being capable of ensuring participation in quality higher education by the diverse groups of the Indonesian society; otherwise those people would have been unreachable or denied access by the conventional face-to-face higher education system. For a long time UT has effectively served working adults and accommodated predominantly older adult students. In recent times, during the past few years, there has been an increasing trend of younger students enrolling in programs and courses offered by UT.

Until now, UT has served as the only national open university serving the community throughout the country and citizens living abroad. Since its beginning, UT has four Faculties, and the number of Study Programs has developed to meet the changing demands of stakeholders and students. In 2005, the UT Graduate Program was established to meet the needs for graduate studies using distance education method at the master's levels.

In order to effectively serve a large number and very diverse groups of student population studying from within the country and overseas locations, the UT has a Head Office (HO) in Jakarta and operates 37 Regional Offices (RO) distributed in almost every province throughout the country. The UT HO serves as the central management office, while the 37 ROs provide and manage frontline services to distance students studying from their respective residences throughout the country. The 2012 statistics indicates that UT has a total of 585,700 students, distributed in its four Faculties and the Graduate Program, as seen in Table 1.

\section{Table 1. Distribution of UT students by Faculty in 2012}

\begin{tabular}{|l|r|r|}
\hline \multicolumn{1}{|c|}{ Faculty } & Students & \multicolumn{1}{c|}{ \% } \\
\hline $\begin{array}{l}\text { Teacher Training and } \\
\text { Educational Sciences }\end{array}$ & 467,969 & 79.90 \\
\hline $\begin{array}{l}\text { Mathematics and Natural } \\
\text { Sciences }\end{array}$ & 4,696 & 0.80 \\
\hline Social and Political Sciences & 87,289 & 14.90 \\
\hline Economics & 23,834 & 4.07 \\
\hline Graduate Program & 1,192 & 0.33 \\
\hline Total & 585,700 & 100.00 \\
\hline
\end{tabular}

Source: UT, 2012

The UT students' demographic profile has dynamically changed to respond to the changing needs of the community, and this should also indicate the credibility and acceptability of the ODL system by the community. Looking at recent statistical trends, it is highly likely that UT will be increasingly accommodating younger age groups in the future through recruitment of recent high school graduates. If such trends continue, the ODL system will be integrated into the mainstream higher education system in Indonesia, where both the UT as an open university and other higher education institutions will go hand and in hand to offer ODL courses accessible by the citizens. According to the 2012 statistics, the age group of UT students can be seen in Table 2.

Table 2. UT student population by age group

\begin{tabular}{|l|r|r|}
\hline \multicolumn{1}{|c|}{ Age } & Number & \multicolumn{1}{c|}{$\%$} \\
\hline$<24$ & 114,730 & 19.59 \\
\hline $25-29$ & 153,801 & 26.26 \\
\hline $30-34$ & 102,400 & 17.48 \\
\hline $35-39$ & 57,108 & 9.75 \\
\hline $40-44$ & 63,720 & 10.88 \\
\hline$>45$ & 93,941 & 16.04 \\
\hline Total & 585,700 & 100.00 \\
\hline
\end{tabular}

Source: UT, 2012

Recent trends during the past few years at UT have indicated changing demographic profiles, geographic residences, and educational as well as professional backgrounds of students. These changes UT students' characteristics should have some ramifications on how UT designs its learning support system for its ODL students. Different groups of students with different characteristics have effects on the node of learning support the intensity on the use of new technology, and learning styles of the students. The younger groups of ODL students generally live in the digital era and are more familiar and get used to using new technology to work and to learn. 


\section{Support system in ODL}

ODL students in an open university needs special attention and services due to their unique needs and characteristics. These groups of students are adults or younger adults, and they have jobs or other commitments, and they pursue university degrees for various purposes, such as professional advancement, occupational mobility, or personal satisfaction. ODL students mostly study from their own locations, in their workplaces or their residences. The UT provides administrative and academic support services to facilitate students' learning in various locations within easy access by the students. Such services are provided increasingly using the online methods, although many students also still prefer the face-to-face mode of interaction, such as face-to-face tutorials. Some practical courses require the development of skills through practice and practicum are conducted in the face-to-face mode, although the UT also provide dry lab available online for the students and other users.

ODL support services are crucial, and the ODL institution has to ensure that all services can reach distance students timely and accurately. These students will have to strive on their own or in group through independent learning or work through the study materials sent to them with the support of tutors and other learning services provided by the institution. The Regional Office of an open university has major responsibilities, such as student recruitment and registration, provision of learning support and administrative services, and examination.

ODL support system includes those core administrative services (registration, information and administrative processing), logistic services (learning, examination and other support materials), and academic services (tutorials and other learning support services). These services can be delivered using the face-to-face, online, or other mediated mode. Student support system in ODL is critical to provide the students with the necessary points of contact for interaction and support throughout their distance learning process.

Considering the large number of students, particularly the in-service teacher students, the UT has since 1990 taken a pragmatic approach to student support system. The UT academic cycle is based on a semester system, and in order to provide effective services to these large numbers of students, the UT has operated in two different groups of students, with each having its own semester academic cycle run almost in parallel sequence. One semester cycle is dedicated to the group of basic education program to serve basic education teachers, known as the Pendidikan Dasar (PENDAS) program. And the other semester cycle is dedicated to the non basic education teacher program to serve the non-basic education teachers, known as the Non Pendidikan Dasar (NON-PENDAS) program. The letter include all programs other than the Primary Teacher Education Program and the Early Childhood Teacher Education Program.

ODL support system covers broad areas, and in this paper, the discussion focuses on the core activities of registration, production and distribution of learning materials, and regional services. These services are provided based on semester academic cycle, and should be able to reach diverse groups of ODL students timely. Accurate support services to students will ensure constructive learning process and successful learning outcome on the part of ODL students. ODL support system must be designed in such a way that the ODL institution can provide support services effectively, and students can utilise them optimally in an ODL environment.

Policies and design of the UT support for ODL students are formulated by the Head Office and implemented by the Regional Office. The UT Head Office serves as the planning and coordinating body, while the 37 Regional Offices act as executing offices that directly interact with, serve and handle ODL students' needs and complaints. The Head Office also provides services to the Regional Offices as its internal customers, while the Regional Office manages and provides services directly to students as its external customers.

\subsection{Student recruitment and registration}

Promotion and development of awareness about UT and its ODL system among the community is the first step to contact potential students. This effort is done in many ways involving meetings with partners, employers and high schools that provide a potential sum of future UT students. Such initial communication with different clients has to be followed up carefully so that potential customers turn to become actual UT students studying in an ODL mode.

Services for ODL students begin with recruitment and registration of students into the ODL system. Recruitment identifies students that need ODL services, while registration ensures entry into the ODL system and thus is the first formal step to become an ODL student. ODL and open university system vary in terms of how they recruit and enrol students into their systems, depending upon the legal and regulatory requirements as well as particular needs of stakeholders'. Many ODL institutions apply open entry admission into their ODL programs without entrance tests, particularly at the undergraduate levels. Most of UT student population falls into the category of undergraduate students admitted without entrance selection, while the UT graduate students have to meet certain criteria and 
require entrance tests for admission to the graduate programs.

At UT, considering the large number of students, a distinct approach to student registration has been adopted to allow an almost parallel two different groups of student categories. Following the UT double cycle each semester, the student registration system is implemented in which students are grouped into two main categories, namely Basic Education Teacher Students (PENDAS) and Non Basic Education Teacher Students (NON-PENDAS).

The PENDAS students are those enrolled the Primary Teacher Education Study Program and the Early Childhood Education Study Program, and they make up to $75 \%$ of the total student population of UT. The PENDAS students register in groups and are provided with distance learning services in study groups of a maximum of 30 students. The face-toface tutorial and other services for these groups of students are provided on the basis of 30 student study group.

The NON-PENDAS students are those enrolled in all Study Programs, including the Graduate Programs, other than those two earlier mentioned. The services provided for the two groups are different. The NON-PENDAS students register individually and many of them study independently on their own, although some of them may attend online tutorials at no charge or on-request face-toface tutorial services at additional charge paid by the students.

Although the registration process generally follow the same procedures, they way registration services are provided to both groups of students are rather different. Services for PENDAS students are clustered in study groups of 20 to 30 students, and thus their registration process is organized in study groups. A typical PENDAS student group will then have to remain in the same group through the years of his/her study, and the study group will receive face-to-face learning support and sit in the same room for the semester exam. In terms of the curriculum structure, the PENDAS students take the same courses already organized for offer every semester to all PENDAS students.

The NON-PENDAS students take courses individually based on the curriculum offered in the study programs. All courses are offered for the $N O N$ PENDAS Study Programs. Some students take more or less courses than others, and students can organize and manage their learning strategies to suit their needs and conditions. NON-PENDAS students register individually and get services based on their individualized needs.

Once the student registration is done, the registration data is stored in the student record system (SRS). Accurate student data is vital for effective ODL planning and management of services, such as production and reproduction of learning materials, provision of face-to-face as well as online tutorials, conduct of examination, and so forth. Once the student data for each semester is finalised all relevant units within UT can plan ahead the logistic support and resources needed to provide ODL services. The student data can accurate tell how many learning materials are to be reproduced and distributed to students, how many face-to-face tutors and tutorial rooms are needed, how many online tutors are to be recruited, how many examination proctors, supervisors and rooms are required to administer trustworthy examinations, and so forth.

\subsection{Production and distribution of learning materials}

Learning process in ODL is designed in such a way that encourages self-directed learning, and the role of the institution is to ensure that ODL students have the opportunity for self direction in learning and develop independent learning capability. Accordingly, the instructional materials is delivered by using variety of learning media, from students have choices that suit their circumstances. At UT, the printed learning materials specially designed for ODL students are the major learning resource for students. These printed learning materials, however, are enriched by non-printed and online learning materials so that ODL students have the opportunity to connect with their learning experiences and competences can be developed more effectively. In other words, the UT learning material packages do not only consist of printed materials but also audiovisual materials such as audio program, video program, and computer-based materials, i.e., computer-assisted instruction, web-based courses.

The development of learning materials is based on the curriculum of each Study Programs. UT implements the course team approach in developing learning materials in order to ensure quality learning materials. UT's learning materials are developed by content experts from well-known universities, instructional designers, evaluation experts, linguistic experts, media specialists, and professional graphic designers and lay-ousters.

Provision of learning materials by ODL institution is the next basic service right after the student data is accurately recorded. The production and distribution of learning materials is critical in ODL, as students will use the learning materials as major learning resources from which they can study independently with or without the help of tutors. Production and reproduction of learning materials are carefully planned based on data of the past four semesters and future trends of the use of learning materials to ensure availability of stock for dispatch to distance students. UT relies on partners for reproduction of learning materials due to the large 
volume and number of courses it has to reproduce timely.

Considering the double cycle each semester for the different groups of UT students, different ways of distributing learning materials to PENDAS and $N O N$ PENDAS students are implemented. Such logistic support services have been designed to meet the curriculum of the different programs.

The PENDAS students take the same curriculum and courses each semester, and services are organized and provided based on study groups. The PENDAS students get the materials to the student groups in their respective locations, and the students then collect the materials themselves.

The NON-PENDAS students buy the learning materials from the Online Bookstore, and they get the materials delivered to their homes. The NONPENDAS take courses in a Study Program and students get services based on individual needs and requests. Accordingly, in order to ensure that students get the learning materials in time, there are some factors that UT considers in distributing learning materials. Those factors are the spread of students' residences, geographical conditions and the availability of transportation, as well as the accuracy and the speed of data processing about needed learning materials [4].

\subsection{Regional support services}

Regional support services for students are provided through the Regional Office (RO) that has the major roles as frontline office, main access point, and service provider to students. The RO is the direct contact for students to get ODL services, including registration, learning support, examination and graduation. The RO implements policies and guidelines of activities set by the UT Head Office (HO). As UT relies on partnership, the RO develops partnership with the local public as well as private partners. For example, the RO has partnership with the local government and institutions for student recruitment. The RO recruits tutors and conduct the face-to-face tutorials in collaboration with the local higher and other education institutions. It also has partnership to ensure examination locations and proctors in the regions.

For UT, a major challenge is to ensure standard services provided by the $37 \mathrm{ROs}$ throughout the country. This has been done through regular coordination, policy communications, meetings, supervisions, and this management coordination are conducted face-to-face as well as using videoconference facilities. ROs have different size of geographical coverage and number of students served, so resources to provide standard services in all ROs have to be distributed proportionally. Training and development of human resources are continuously provided and staff performance is regularly monitored.

\section{Learning support in ODL}

Student learning support services are provided in order to facilitate student to be successful in their learning process. The availability of tutorials, are intended to assist students in mastering learning materials and solving their learning problems. There are various modes of tutorials that UT provides, such as face-to-face tutorial and mediated tutorials (via radio, television, and internet). Since students are encouraged to interact with other students, tutorials can also be an arena for them to motivate each other to be independent students through peer tutoring. Meanwhile counselling service is more aimed at helping students to solve their administrative academic and personal problems in taking courses. Both face-to-face and online tutorial processes are facilitated by tutor, and they follow similar guidelines in terms of frequencies of tutorials. There are eight sessions of tutorials in the face-to-face tutorial or eight initiations in the online tutorial and three tutorial assignments that students have to accomplish for each course. Students' participation and the results of tutorial assignments have contributions to the final course grade.

Face-to-face tutorials are managed by RO and take place in locations close to students' residences. All of ROs provide face-to-face tutorials. At the second semester of 2011, there were 411 graduate courses for which ROs provided face-to-face tutorials and 887.492 students who attended the tutorials (133.640 of the NON-PENDAS students and 753.852 of the PENDAS students).

To conduct face-to-face tutorial, UT has 30,926 tutors registered in UT's tutorial data base since 2001. There were 15,484 tutors who conducted tutorials in the second semester of 2011. These tutors are lecturers from other local universities and other educational institutions, senior teachers, as well as practitioners. Since tutorial is different from teaching, UT conducts training for new tutors and reorientation programs for registered tutors. Tutorial training and tutor evaluation as part of the process of accreditation programs are conducted as part of the effort to improve the quality of face-to-face tutorials. Besides that, staff at ROs also conduct monitoring and evaluation of face-to-face tutorials.

Regarding the increasing use of ICT in the learning process, UT also provides online tutorials. In the first semester of 2011, there were 649 courses offered with online tutorial services, and 23,504 students participated in online tutorials. In the second semester of 2011 there were 628 online courses offered and 27,774 students participated in online tutorials. Most of online tutors are UT academic staff based in HO and RO. In comparison with students' 
participation in online tutorial in the previous year, the number indicates an increase of almost $100 \%$ in the first semester and more than $100 \%$ in the second semester. The number of students who participated in online tutorials in the first semester of 2010 was 12,371 , and in the second semester of 2010 were 13,609 [6].

In terms of counselling services, both staff in $\mathrm{HO}$ and ROs provides opportunities for students to ask for alternative solution for their problems. In general, problems that students faced in their study are related to registration process, obtaining learning materials, applying for credit transfer, activation of online tutorials, course grade, and change of the personal identity. In counselling service, students can directly come to the Student Service Unit either in $\mathrm{HO}$ or RO. Besides, counselling services are facilitated by online Customer Relationship Management that can be accessed by students via UT website. By providing counselling service, students will obtain alternative solution to handle their problems so that they can finish their study in accordance with their plan.

Besides tutorials and counselling, other students learning support that UT provides are online selfexercise, web-supplement, digital library, Internet TV (I-TV), Online Smart-Teacher Portal (Portal Guru Pintar Online-GPO), online tutorial kits, and dry lab. The use of online services by students and access to online services by students and other users have been increasing recently.

Such student learning support services that UT provides are related to the primary functions of student support in ODL, namely cognitive, affective, and systemic functions [5]. UT provides tutorials and online supplementary learning materials to support and assist students' learning process (cognitive function) as well as to facilitate them to interact and motivate each other (affective function), and counselling service to help students in managing their administrative academic and learning problem (systemic function).

\section{Examination}

Examination is conducted to measure students' achievement in mastering a course and in completing the program that they take. A course grade is determined by the results of tutorial assignments (for course with tutorial services) and of practice/practicum assignments (for courses that require practice/practicum), as well as semester examination. Tutorial and practice/practicum assignments are administered at the tutorial meetings. Meanwhile, semester examination is administered at the end of every semester. It is conducted as supervised paper and pencil test simultaneously at the appointed location throughout the country. Especially for the graduate program, students are required to write Master Program's Final Assignment (thesis) and pass the final oral examination.

In addition to paper and pencil test, UT provides online examination for students who take courses that semester examination schedules are administered at the same time. In order to ensure the confidentiality and security of examination materials, both paper-and-pencil test and online examination, UT has implemented a computerised Test Item Banking System [3].

UT administers four times of semester examination a year, those are two for the $N O N$ PENDAS Program and the other two for the PENDAS Program. As illustration of the load of examination process, in the first semester of 2011 , UT administered semester examination of the NONPENDAS Program in 288 places in the country with 83,953 students and in 14 places overseas with 645 students. Meanwhile semester examination for the PENDAS Program was administered in 466 places with 355,825 students. In the first semester of 2011, the Examination Centre proceed 2,309,165 examination results.

In order to speed up the processing of examination results in relation to accurate student identity, UT implements a digital printing system in producing the examination manuscripts which include individual personal identity of each of the test takers (UT Rector's Annual Work Report of 2011). This digital printing system has been implemented since the second semester of 2011 for the NON-PENDAS program in all ROs. However, for the $P E N D A S$ program the implementation of digital printing for semester examination has started with 15 ROs in the first semester of 2012.

\section{Information and communication technology (ICT) in ODL management and learning support}

There is no doubt that ICT has vital roles in ODL management and learning support. As new technologies develop, ODL system has to embrace and adopt new technologies that best develop the capability of the institution to serve its students and provide the best benefit to its students. ICT has continuously enhanced the quality ODL services and made ODL more accessible to its students in a variety of ways.

For the case of UT that has over half a million students, a good and reliable ICT system is necessary to ensure good management and learning support for diverse groups of students with different level and ease of access to ICT. A reliable ICT system has been designed by UT aiming optimally at developing UT as enabler for effective ODL services. The UT 
ICT services are directed to meet and ensure provision of the following services.

- Accurate, secure, effective and efficient services;

- Valid and updated data;

- Reliable services to different stakeholders;

- Effective services for students or users with different levels of ICT capabilities;

- Accessible facilities for online learning in the forms of learning materials, tutorials, research, and other means of support services.

In order to support this kind of ICT support, the UT has developed an integrated network of Head of Office and its 37 Regional Offices through a virtual private network (VPN) so that data entry conducted at the Regional Office can be periodically transmitted to and synchronised with the Head Office database. This data is then further synchronised with partners, such as the partner banks, so that students can pay fees appropriately through the nominated partner bank. Apart from data communication, this VPN network is also used to communicate sounds and graphics. Furthermore, the internet is used as link backup to support the existing VPN system.

\section{Quality assurance in ODL support system}

Quality assurance (QA) in ODL is important, as ODL has to provide services that meet diverse needs and requirements of students. By implementing a comprehensive QA system, UT can ensure that its student and operational services has been met increasingly high standard and make the public confidence on it (Belawati, 2010). At UT a systematic and comprehensive QA system has been effectively implemented involving both internal and external assessment and audits. A QA Centre has been established since 2003 with responsibilities to manage and coordinate implementation of QA system university wide.

The UT QA system has integrated both internal and external criteria. Internal QA system has been developed and linked with external QA criteria set by the National Board of Educational Standard, National Board of Higher Education Accreditation, Internal Quality Assurance System of the Ministry of Education and Culture. International benchmarking is done through looking at statement of best practices by the Asian Association of Open Universities and criteria set by International Council for Open and Distance Education. Referring to these international benchmarks in ODL, UT has established its own quality assurance system since 2003, and recently it has updated its QA system since 2012.
Internal as well as external quality audits and reviews are conducted periodically, coordinated by the UT QA Centre. Internal audits involve lots of internal quality auditors who work in different units in Head Office as well as Regional Offices. Internal quality audits provide feedback for continuous improvement and prevention from defects in terms of process and products. In terms of external quality reviews, the National Board of Higher Education Accreditation (BAN-PT) conducted visits and reviews in 2011 based on Study Program Accreditation so that all UT Study Programs are accredited by the Board. The International Council of Open and Distance Education (ICDE) also conducted quality reviews of UT twice in 2005 and 2010 respectively. Thus UT has greater confidence and public credibility in terms quality based on the results of the external quality agencies.

UT has also adopted the ISO 9001 quality management system as part of quality assurance of its student and operational services. The ISO 9001 approach has been used in its core business services such as distribution of learning materials, production of learning and examination materials, academic administration, distance learning services of the Regional Office, and promotion and cooperation. The ISO 9001 approach has been consistently implemented since 2006, and continuous improvement and prevention has been implemented to ensure that the system and services the UT provides meets student expectations and stakeholders' requirements.

Ensuring effective implementation of internal QA system and meeting various kinds of external quality criteria is significant challenge to address by ODL institution. For UT, external QA and accreditation agency has different quality criteria and assessment instruments the UT has to meet. There may also be different views and opinions about quality, quality assurance, and QA in ODL. Quality reviewers may further have different views and expectations, and even lack of understanding about ODL concepts and processes. Thus developing awareness of ODL and QA in ODL needs to be further continued so that common perceptions can be achieved and quality reviewers can have objective assessment of quality ODL.

\section{Conclusion}

Student support services in ODL need continuous improvement and enhancement to ensure that such services meet the expectations of students and stakeholders. ODL system has moved towards more individualised services to students using the technology available to students. For UT, there has been increasing interests of its students to use online services, and this can be seen in the increasing number of students participating in online tutorials. 
UT has also attempted to improve its online services in the operational areas of including registration, learning support and examination. The challenge for UT is to continue to adapt to the changing needs of its students and develop innovations in the use of new technology to reach more diverse groups of students and improve the quality of academic and administrative services using new technology.

It is important to note that ODL system should meet stakeholders' requirements and students' learning circumstances. Effective ODL support system should be designed to facilitate student learning and help students develop independent learning capabilities.

\section{References}

[1] Belawati, T. (2010). Quality Assurance. In Tian Belawati and Jon Baggaley (Eds.), Policy and Practice in Asian Distance Education. India: SAGE Publications. Pp. 49-58.

[2] edX. (2012). The Future of Online Education

For anyone, anywhere, anytime. Downloaded from https://www.edx.org/, 19 September 2012.

[3] Puspitasri, K.A. (2010). Student Assessment. In Tian Belwati and Jon Baggaley (Eds.), Policy and Practice in Asian Distance Education. India: SAGE Publications. Pp. 60-67

[4] Soleiman, N. \& Listyarini, S. (2004). Pengelolaan Distribution Bahan Ajar di Universitas Terbuka. In Asandhimitra (Ed.), Pendidikan Tinggi Jarak Jauh. Jakarta: Universitas Terbuka. Pp. 631-662.

[5] Tait, A. (2000) 'Planning Student Support for Open and Distance Learning', Open Learning (15), 3, pp. 287299.

[6] Universitas Terbuka dalam angka [Universitas Terbuka in figures], downloaded from http://www.ut.ac.id/tentangut/ut-dalam-angka.html, 7 May 2012.

[7] Universitas Terbuka Rector's Annual Work Report of 2011. 